\title{
Comparative ecosystem trophic structure of three U.S. mid-Atlantic estuaries
}

\author{
Mark E. Monaco ${ }^{1, *}$, Robert E. Ulanowicz ${ }^{2}$ \\ 'NOAA - N/ORCA 1, 1305 East-West Highway, Silver Spring, Maryland 20910-3281, USA \\ ${ }^{2}$ University of Maryland, Chesapeake Biological Laboratory, Box 38, Solomons, Maryland 20688, USA
}

\begin{abstract}
Quantitative networks of trophic exchanges offer the potential to compare food webs from neighboring ecosystems in order to ascertain whether large differences and similarities exist in trophic structure and function. Network analysis was invoked to compare the exchanges of carbon in 3 midAtlantic estuaries on the eastern U.S. coast: the Narragansett, Delaware, and Chesapeake Bays. Narragansett Bay exhibited the highest average annual rate of net primary production, followed by Delaware and Chesapeake Bays. Taken in combination, the analyses of cycling structures (magnitude of flows, average carbon cycle lengths), organization of carbon flows, system production:biomass ratios, and harvest rates all indicated that the Delaware and Chesapeake Bay ecosystems are more stressed than that of Narragansett Bay. To differentiate between the former two, a combination of measures of system efficiency, cycling structure, and food web connectivity was employed. The results indicated that Delaware Bay is currently less impacted and has potentially more ability to mitigate perturbations to its food web than does Chesapeake Bay. Overall, network analysis proved to be a suitable methodology for making inter-estuarine ecosystem comparisons, and for providing useful insights to natural resource managers in the assessment of estuarne trophic structure and status.
\end{abstract}

KEY WORDS: Network analysis · Food webs · Carbon flows - Estuaries

\section{INTRODUCTION}

Estuaries exhibit differences in their physical habitat characteristics and trophic status; thus, our ability to understand ecosystem-level impacts of anthropogenic and natural phenomena is limited. Urgently needed is a strategic approach that predicts the development of community structures and the functional responses of ecosystems in response to different environmental impacts (Gaedke 1995). However, the dynamics and regulation of food webs cannot be understood unless one also considers simultaneously processes occurring at the species or guild level, as they act in concert with those distributed over the domain of the entire ecosystem. To address this need, we have developed and analyzed energy flow in estuarine food webs from 3 mid-Atlantic estuaries on the eastern U.S. coast using

·E-mail: mark.monaco@noaa.gov network analysis (Ulanowicz 1986). The results, taken as a whole, permitted the comparative analysis of estuarine trophic structure.

The functioning of estuaries integrates complex interactions of physical, biogeochemical, and biological processes (Baird et al. 1991). The magnitudes of biological throughput, and the physical scales over which individuals and populations interact, are important factors in determining the spatial and temporal variability of ecosystems (Baird et al. 1991). Recent comparisons of material and energy flows between various ecosystem components have shown that the efficiency with which material is transferred, assimilated, and dissipated conveys significant information about the fundamental structure and function of the whole ecosystem (Ulanowicz \& Platt 1985, Baird \& Ulanowicz 1989, 1993, Baird et al. 1991, Ulanowicz \& Wulff 1991). The network analysis algorithms used in these comparisons are derived from input-output analysis, trophic and cycle analyses, and the computa- 
tion of total system properties such as ascendency, throughput, and development capacity (Kay et al. 1989).

Network analysis recently has been used to compare ecosystems of different size, geographic location and trophic status (Baird et al. 1991, Ulanowicz \& Wulff 1991. Baird \& Ulanowicz 1993). Absent from the literature, however, are comparisons of estuaries that are close geographically (e.g. same biogeographic province), yet differ in trophic status, and exhibit disparate bio-physical and hydrological characteristics. Therefore, the objective of this investigation was to quantify food webs from neighboring estuarine ecosystems in order to perform comparative food web or network analyses of their trophic structures, to ascertain whether large differences and similarities could be identified.

Monaco (1995) identified assemblages of estuaries based on physical and biological characteristics, and used these groupings to define estuarine biogeographic regions along the U.S. east coast. Based on these estuary assemblages, 3 representative estuaries were selected possessing unique physical, biological and trophic characteristics from the Virginian biogeographic province (Briggs 1974): Narragansett Bay, Delaware Bay, and Chesapeake Bay (Fig. 1). Each. of these estuaries has been anthropogenically stressed (e.g. nutrient loadings) during recent decades (Goodrich 1986, NOAA 1987, McCoy 1988); however, it is not obvious which is most heavily impacted, nor has the response of each ecosystem been easy to characterize.

\section{METHODS}

This comparative estuary food web investigation examined energy flow networks by means of network analysis, which quantifies input-output relationships (Leontief 1951), cycling (Finn 1976), through-flows, storage, information theory indices (Ulanowicz 1986), and diet relationships. The details of the underlying theoretical concepts and methodology for analyzing ecosystem structure are provided in Ulanowicz (1986), Kay et al. (1989), and Christensen \& Pauly (1992a).

Network analysis software. Energy budgets for each estuary were developed using the ECOPATHii software, which determined the budget for each trophic group using a series of linear equations (Christensen \& Pauly 1992a). ECOPATHii combines an approach by Polovina (1984) for estimating production and consumption by various compartments with Ulanowicz's (1986) analysis of the flows between compartments. The software is described in detail by Christensen \& Pauly (1992a).

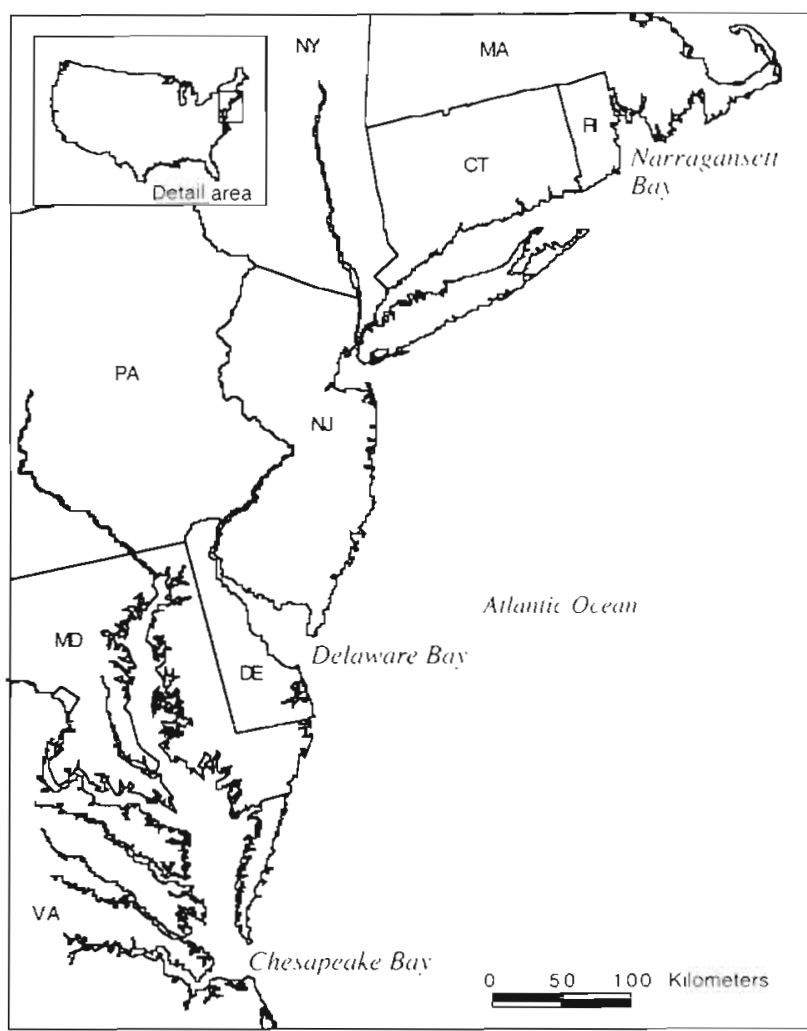

Fig. 1. Location of Narragansett, Delaware, and Chesapeake Bays along the U.S. east coast of North America

Equally important was the NETWRK software that was employed primarily to analyze the structural features of carbon flows and to characterize indices of overall trophic structure (Ulanowicz 1987). The analyses enabled quantification of the response of an estuary's ecosystem throughout its food web, not simply as it occurs among the phytoplankton or apex predators. A detailed presentation on the input of data to NETWRK and the interpretation of its outputs is given by Ulanowicz \& Kay (1991) (see also the website http://www.cbl cees.edu/ ulan/ntwk/network.html).

The energy networks for Narragansett and Delaware Bays were developed as part of this study, and the Chesapeake Bay network was modified based on Baird \& Ulanowicz (1989). Estuary-specific compartmental (guilds) biomasses, production to biomass ratios, diet matrices, and detrital inputs were entered into the network analysis software. The results, which appeared in terms of carbon biomass from the ECOPATHii and NETWRK software, allowed comparisons across estuaries using a 'common language' and comparable methods. For each estuary, comprehensive networks of energy flows were estimated, with the total number of ecosystem compartments ranging from 32 to 37 (Monaco 1995). 
The efficiency with which energy is transferred and assimilated conveys information about the fundamental performance of the entire ecosystem (Ulanowicz \& Wulff 1991). However, several important criteria must be satisfied before one can compare network analysis results across different ecosystems (Baird \& Ulanowicz 1989, 1993). First, the flow topology, and the degree of aggregation among the living compartments must be nearly the same in the systems being compared, and the production:biomass $(\mathrm{P} / \mathrm{B})$ ratios of individual species to be aggregated also must be similar (Christensen \& Pauly 1992a). Second, the same medium or currency must be used for all estuaries. In addition, the resolution of any comparison of multiple ecosystems is dictated by the least resolved (i.e. largest) spatial and temporal intervals, and the most aggregated taxonomic groupings, for which data from each estuary are available. In this study, all trophic networks were aggregated into 13 or 14 species guilds (compartments), and carbon (C) was the common currency. However, each network did not contain an identical list of guilds for each estuary. Compartments that are not naturally present, or that have a minimal role in an estuary's food web, were not included. The aggregated carbon flow networks for each estuary are shown in Figs. 2, $3 \& 4$. The Chesapeake network consisted of 13 compartments, while the Delaware and Narragansett Bay networks were comprised of 14

Network estimates. An energy flow estimation network requires information on the biomass of living and nonliving estuarine ecosystem components, the diets of all feeding species, and the rates of energy transfer among the various entities in the food web. The best available information was compiled or calculated to develop each estuary network. The majority of the biomass, diets, and trophic transfer data were readily available for the well-studied Narragansett, Delaware

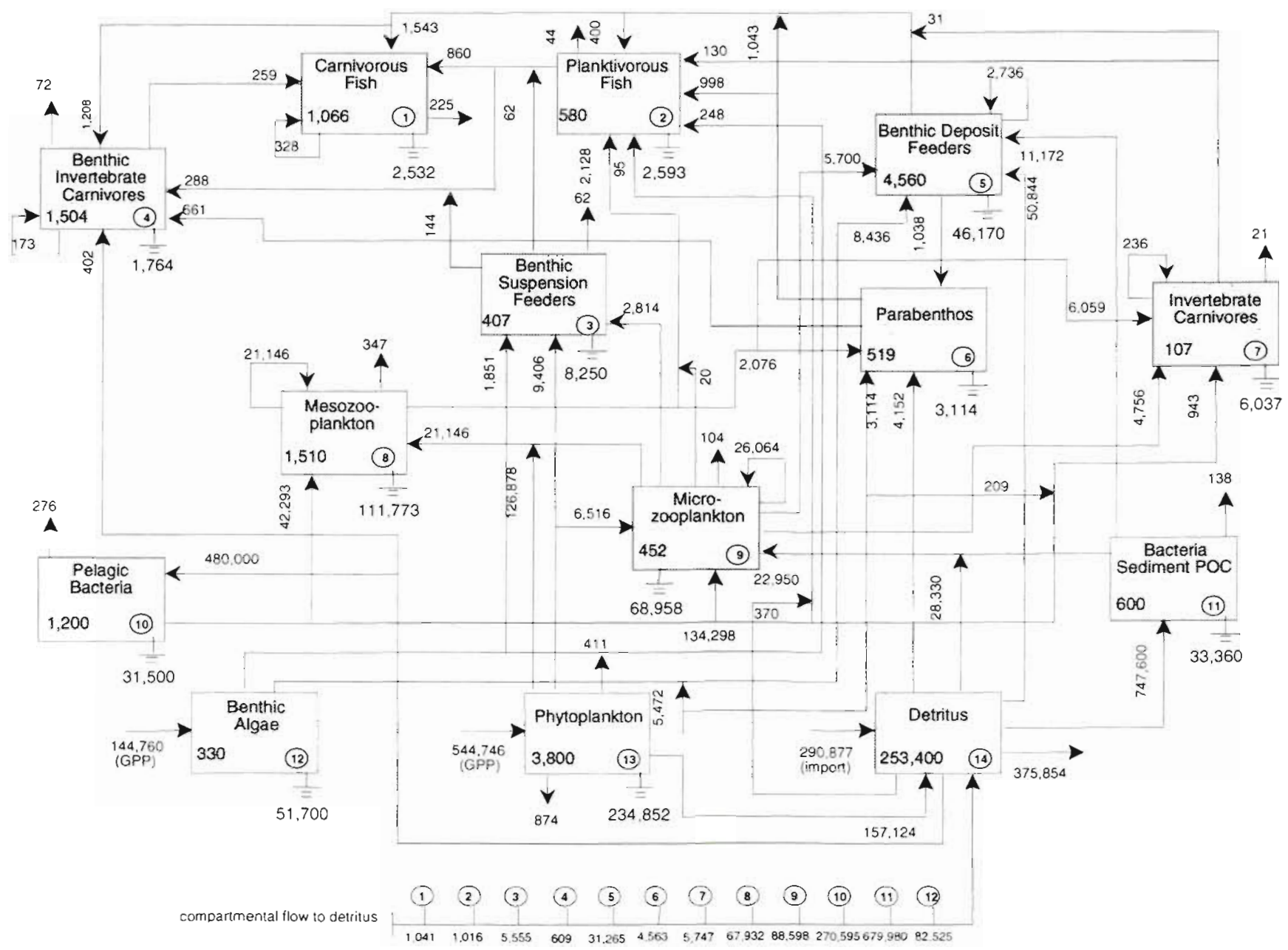

Fig. 2. Average annual energy flow $\left(\mathrm{mg} \mathrm{C} \mathrm{m}^{-2} \mathrm{yr}^{-1}\right)$ and compartmental biomass $\left(\mathrm{mg} \mathrm{C} \mathrm{m}^{-2}\right)$ in Narragansett Bay 


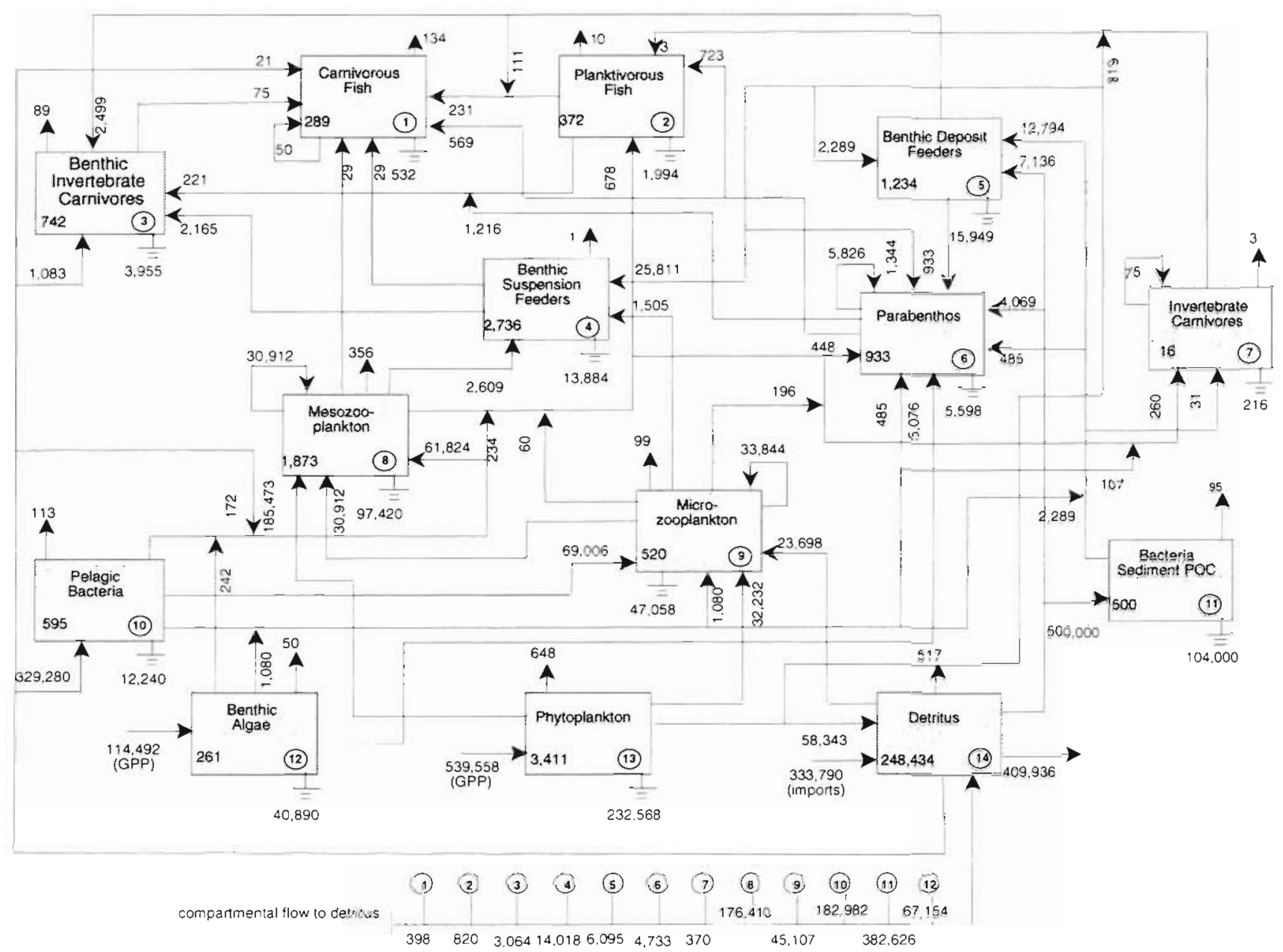

Fig 3. Average annual energy flow $\left(\mathrm{mg} \mathrm{C} \mathrm{m}^{-2} \mathrm{yr}^{-1}\right)$ and compartmental biomass $\left(\mathrm{mg} \mathrm{C}^{-2}\right)$ in Delaware Bay

and Chesapeake Bays (Monaco 1995). At the lower trophic levels (e.g. bacteria) some 'generic' trophic parameters were obtained from the literature, such as consumption to biomass ratios, and were used to calculate carbon budgets (Coffin \& Sharp 1987, Monaco 1995)

Monaco (1995) calculated and/or compiled the average annual biomasses of living and non-living compartments in each estuary as the starting point from which to develop an energy budget for each compartment. The annual biomass of each compartment was reported as $\mathrm{mg} \mathrm{C} \mathrm{m}^{-2}$ and fluxes as $\mathrm{mg} \mathrm{C} \mathrm{m}^{-2} \mathrm{yr}^{-1}$. In most cases, the next step was to obtain estuary-specific estimates of the diets and consumption rates for each predator. Monaco (1995) provides a detailed discussion on the methods and estuary-specific references by parameter that were used to estimate the energy budgets for each compartment.

Gross primary production by the autotrophic compartments (phytoplankton. and benthic algae) was assumed to equal the sum of net primary production plus algal respiration. These gross production estimates constituted the major inputs to each estuary. The net primary production was then partitioned among consumers according to reported herbivore diets and consumption requirements.

Estimates of consumption, production, and respiration generated by ECOPATHii were imported into NETWRK to calculate annual carbon budgets for each heterotrophic compartment during each year. The balance equation $\mathrm{C}=\mathrm{P}+\mathrm{R}+\mathrm{E}$ was used, where $\mathrm{C}=$ consumption rate, $\mathrm{P}=$ secondary production, $\mathrm{R}=$ respiration, and $\mathrm{E}=$ egestion (Levinton 1982). The carbon available to the next compartment in the food web was allocated to predators based on their diet demand, and the remainder to detritus and export. To supplement the data generated by ECOPATHii, values on the biomass or energetics of other species or guilds were compiled either from estuary-specific studies or estimated using $\mathrm{P} / \mathrm{B}$, consumption/biomass $(\mathrm{C} / \mathrm{B})$, and produc- 


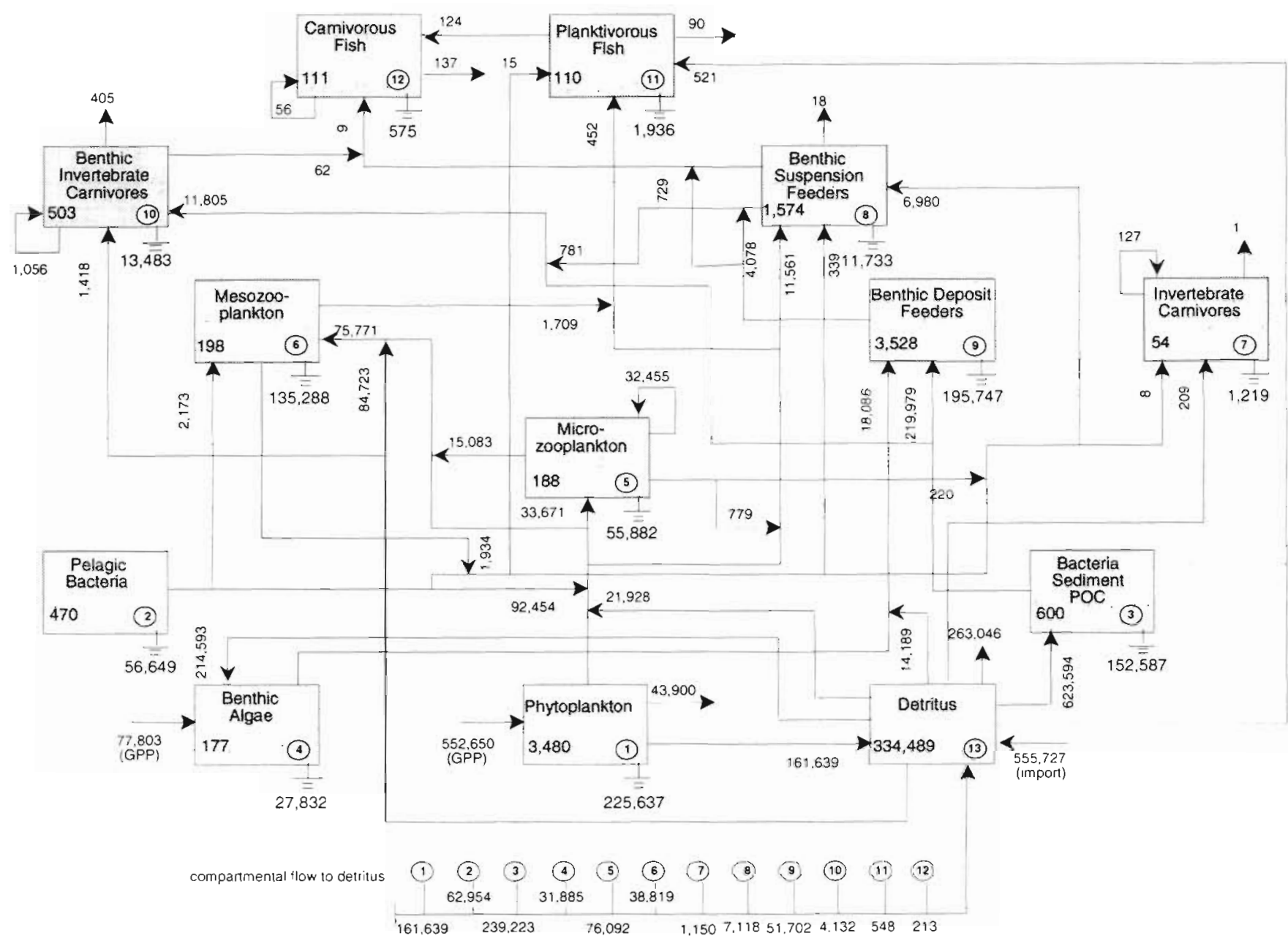

Fig. 4. Average annual energy flow $\left(\mathrm{mg} \mathrm{C} \mathrm{m}^{-2} \mathrm{yr}^{-1}\right)$ and compartmental biomass $\left(\mathrm{mg} \mathrm{C} \mathrm{m}^{-2}\right)$ in Chesapeake Bay

tion/respiration (P/R) ratios (e.g. Day et al. 1973, Jorgensen 1979, Mann 1982, Christensen \& Pauly 1992a, Monaco 1995).

A complete network analysis requires estimates of rates of export from a system, including harvests of economically important species. Commercial landings data from each estuary were obtained from NOAA's National Marine Fisheries Service (NMFS) Fishery Statistics Division for the time period 1980 to 1990 (NMFS 1993, 1994). These data were organized by Lowery \& Monaco (1995) to provide estimates of harvest in $\mathrm{mg} \mathrm{C} \mathrm{m} \mathrm{m}^{-2}$. Also, estimates of recreational harvest were obtained for each study area from the literature (NOAA 1991, 1992).

Estuarine ecosystem comparisons. Compartmental trophic structure: Levine (1980) used the algebraic powers of the diet matrix to show how the amounts arriving at various trophic distances from primary sources can be used as weighting factors to estimate the average trophic level at which each guild is feed- ing. Each compartment in a food web can thus be assigned a point along a trophic continuum, and the relative values of this trophic index as it pertains to each taxon can be compared between estuarjes. The average trophic level (ATL) of each compartment is shown in Fig. 5. The aggregation of species into trophic guilds, e.g. carnivorous fish, was based on those species having approximately the same overall trophic position, $\mathrm{P} / \mathrm{B}$ ratio, and diet or feeding strategy.

Although observations on direct trophic interactions reveal much about an ecosystem's dynamics, they do not explicitly reveal the many important indirect interactions. Using the trophic direct interaction data within an estuarine community, it is possible to calculate the indirect influences that members, lacking immediate contact, have on one another (Ulanowicz 1986). Szyrmer \& Ulanowicz (1987) used the predator/prey (diet) matrix to calculate the degree to which the diet of any particular compartment depends, directly and 
indirectly, on the production of any other member of the ecosystem. The sum of all of the algebraic powers of this diet matrix yields the total dependencies of each predator species across all prey.

Cycling structure: The cycling of material and energy in ecosystems is generally considered an important aspect of ecosystem function that contributes to autonomous ecosystem behavior (Odum 1969, Ulanowicz 1986, Baird \& Ulanowicz 1993). A cycle is a trophic pathway in which the arbitrary starting and ending compartments are the same (Ulanowicz \& Wulff 1991). Cycling of carbon in estuaries can occur through a number of cycles that vary in the numbers of transfers they contain. In each cycle, one can identify a weak arc as that connection through which the smallest flow occurs. Very often, any particular arc is part of more than one cycle, and all cycles that collectively share the same weak arc are grouped into what is called a nexus (Ulanowicz \& Kay 1991).

While the number of cycles within a trophic network is important, it is also necessary to consider whether cycling occurs over short and fast routes, or over longer and slower loops (Baird et al. 1991). Hence, 4 measures of cycling were used in this study: (1) the number of cycles and how they were distributed according to cycle lengths, (2) the topology of estuary cycling, (3) the Finn Cycling Index (described below), and (4) the cyclic and acyclic average path lengths (APL).

Ecosystem indices: Ulanowicz (1986) has characterized the developmental status of an ecosystem network in terms of a suite of whole-system indices that are defined by applying information theory to the flow structure. Several such global measurements of ecosystem organization are calculated in NETWRK, including: total system throughput ( $T$ ), which is the sum of the magnitudes of all flows that occur in an estuary ecosystem. It is a surrogate for the size of an ecosystem in terms of overall activity (Ulanowicz 1986. Kay et al. 1989). Ulanowicz (1986) scaled the mutual information of a network (organization) by the network's activity (total system throughput), and named the product the system ascendency $(\mathrm{A})$. Ascendency is the key index that characterizes the degree of system development and maturity (Ulanowicz 1986). It represents both the size ( $T$ ) and the organization (average mutual information) of flows.

Ulanowicz (1986) has suggested that both the number of trophic compartments (guilds) and the extent of trophic specificity (the relative lack of trophic niche overlap) are embodied in the average mutual information of the flow connections between compartments. A network with high mutual information is a system with many nodes (compartments) of comparable size that are connected linearly with each other (Baird et al. 1991)

According to information theory, a natural limit to the ascendency would be the development capacity (Cd) (Ulanowicz 1986). Development capacity is the joint uncertainty of the flow connections (according to the Shannon-Wiener formula), normalized by total system input (Ulanowicz \& Norden 1990). Because the Shannon-Wiener index is an upper bound on the mutual information, $\mathrm{Cd}$ may be identified with the capacity of the system for further development. Flow diversity is the Shannon-Wiener formula applied to the probability that a unit of carbon passes from a particular compartment to another specified compartment Because flow diversity is calculated using the logarithmic Shannon-Wiener measure of complexity, small differences in the value of this index can reflect much larger quantitative disparities (Ulanowicz 1986).

Ulanowicz (1986) suggested that organization in ecosystems is intimately coupled with the average degree of trophic specialization. No ecosystem can be perfectly organized, and the complement to ascendency is overhead (Baird et al. 1991). Overhead is generated by structural ambiguities deriving from multiplicities in the system inputs, exports, dissipations (respirations), and internal exchanges (redundancy). The ascendency and overhead together constitute the system's capacity for development (Ulanowicz 1986). The capacity minus ascendency represents the amount of the development capacity that does not appear as organized structure or constraints (overhead) on the ecosystem. On the downside, the overhead represents the cost to an ecosystem to circulate material and energy the way it does. The magnitudes of, and uncertainties in, the origins of the imports, exports and respirations contribute to system overhead.

The internal redundancy is that component of the overhead that is engendered by parallelisms in the internal pathways of trophic transfers. Overall, the overhead comprises what is commonly regarded as inefficiencies in operation or ambiguities in structure (Baird et al. 1991). Ulanowicz \& Norden (1990) suggest that overhead represents the degrees of freedom a system has at its disposal to respond to a novel perturbation.

The degree of system development can be regarded as the fraction of possible organization that is actually realized, i.e. A/Cd (Ulanowicz \& Mann 1981). A characteristic of highly organized systems is their tendency to internalize most of their activity (flow), thereby becoming relatively indifferent to outside supplies and demands. For this reason, Ulanowicz \& Norden (1990) emphasized the internal components of $A$ and $\mathrm{Cd}$ that are generated solely by the internal 
exchanges within a network. The relative internal ascendency $(\mathrm{Ai} / \mathrm{Ci})$ is a dimensionless ratio of the internal components that excludes the influence of $T$ (the growth component) on $\mathrm{Ai}$ and $\mathrm{Ci}$. This index represents the balance between the efficiency of carbon flow and system redundancy (i.e. linear vs web-like food chains). This index is most suitable for comparing different ecosystems (Field et al. 1989, Mann et al. 1989, Baird et al. 1991).

Estuaries with a relatively high value of $\mathrm{Ai} / \mathrm{Ci}$ may be considered well organized, and therefore, unlikely to disintegrate spontaneously (Baird et al. 1991). They possess significant internal stability that makes it difficult for a new endogenous influence to change their configuration. The lack of redundancy, however, could leave the system vulnerable to exogenous stresses. Thus, a trade-off must occur between estuarine ecosystem ascendency (efficiency of flow) and redundancy or complexity of pathways.

System-level food chain interactions can be characterized by Christensen \& Pauly's (1992a) system omnivory index (OI). This system-level index is defined as the average omnivory index of all consumers weighted by the logarithm of each predator's food intake (biomass multiplied by the $\mathrm{C} / \mathrm{B}$ ratio). When the guild-specific OIs are summed and averaged, the system (estuary) level index is a measure of how broadly the feeding interactions are distributed among trophic levels. The dimensionless index ranges from 0.0 to 1.0 . A value of 0.0 indicates that the consumer is highly specialized, and values approaching 1.0 indicate feeding on many trophic levels.

\section{RESULTS AND DISCUSSION}

\section{Ecosystem properties}

To decipher the information contained within each estuary's energy flow network (Figs. 2, 3 \& 4), a series of tabular outputs are presented and described. Table 1 provides the summary statistics for each estuary. Together, Tables $1 \& 2$ provide the results from network analysis that were used to characterize estuarine ecosystem trophic structure. Tables $3 \& 4$ characterize the magnitude and structure of carbon cycling.

Due to the complexity of the input parameters for network analysis indices, no statistical tests of significance currently exist to evaluate differences in the values of various indices across ecosystems. However, the network trophic structure and estuarine ecosystem property results, when taken in whole and based on rank ordering, provide definitive patterns indicating the trophic structure, complexity and relative stress exhibited by each estuary.

\section{Comparative assessment}

The present study has attempted to determine whether differences and similarities among estuarine food webs can be identified between geographically close estuaries. Although US mid-Atlantic estuaries exhibit common characteristics, such as salinity patterns and magnitudes of tidal energy, network analysis revealed both similarities and differences between the trophic structures that were not superficially apparent.

\section{Production and biomass}

Because the estuary networks are based on steady state inputs and outputs, it is important to examine the standing crop and rate of primary production of the 3 estuaries. Narragansett Bay exhibited the highest rate of net annual average primary production, followed by Delaware and Chesapeake Bays (Table 1). Most estuaries along the mid-Atlantic seaboard receive large loadings of nitrogen and phosphorus that fuel the production of phytoplankton. In each estuary, primary production is dominated by pelagic phyto plankton. The ratio of pelagic to benthic primary production varies, however, from 3:1 (Narragansett Bay) to $6: 1$ (Chesapeake Bay), with an intermediate ratio (4:1) in Delaware Bay.

Less impacted systems are presumed to have higher values of net system production (Odum 1969), suggesting that Narragansett Bay was the least impacted of the 3 bays (Table 1). Chesapeake Bay had a negative net system production, which can be explained primarily due to the large amount of organic material imported into the system from its large drainage basin.

The detritivory/herbivory $(\mathrm{D} / \mathrm{H})$ ratio is the ratio between detrital consumption (uptake from detritus) and direct grazing on primary producers and is an indicator of surplus production. The ratio for each bay was: Narragansett, 8.1; Delaware, 3.4; and Chesapeake, 6.9. Delaware Bay exhibited a more effective direct utilization of primary production when compared to the other bays (Table 1) as also reflected in its low $\mathrm{D} / \mathrm{H}$ ratio. The Delaware estuary is very turbid compared to other U.S. east coast estuaries, and there is relatively efficient use of primary production in the lower estuary, where over $90 \%$ of total phytoplankton production occurs (Pennock 1985). The ability of the Delaware ecosystem to recycle primary production products may be limited, however.

The mean Lindeman trophic efficiencies in each system ranged from $12.5 \%$ in Delaware Bay to $17.4 \%$ in Chesapeake Bay (Lindeman 1942, Monaco 1995, Ulanowicz 1995). Thus, U.S. mid-Atlantic estuaries all appear similar, with trophic efficiencies averaging 
ca $15.0 \%$. This average is not too different from the often-assumed $10 \%$ efficiency between trophic levels (Levinton 1982). One would expect trophic efficiency in estuaries to be somewhat greater as compared to a 'global' average. This was corroborated by relatively low connectance indexes for each estuary (Christensen 1992), indicating that U.S. mid-Atlantic estuaries have more linear-like (i.e. efficient) food chains (Table 1).

Baird \& Ulanowicz (1993) found an inverse correlation between net primary production (NPP) efficiencies and the $\mathrm{D} / \mathrm{H}$ ratio. The same correlation was observed in this study, as Narragansett and Chesapeake Bays exhibited high $\mathrm{D} / \mathrm{H}$ ratios and relatively low NPP efficiencies. These 2 estuarine ecosystems rely heavily on detritus inputs and recycling via the microbial loop. The low $\mathrm{D} / \mathrm{H}$ ratio and high NPP in Delaware Bay suggest a greater diversity of resource utilization, which is in accordance with the system's higher OI (more web-like structure across trophic levels).

Chesapeake Bay exhibited the largest system $B / P$ ratio. This ratio may not reflect system stress or maturity, but rather is indicative of adaptation to the physical environment or the degree to which production is retained within the estuary. The $\mathrm{B} / \mathrm{P}$ ratio is also sensitive to the number and size of organisms within a system (Christensen \& Pauly 1992b). Thus, it was not surprising that Delaware and Chesapeake Bays, which exhibit relatively slow flushing rates (Nixon 1983) and have a relatively high number of species, should yield higher $\mathrm{B} / \mathrm{P}$ ratios.
Table 1 Summary of ecological statistics/indices for estuary networks. GPP gross primary production; NetPP: net primary production

\begin{tabular}{|c|c|c|c|}
\hline $\begin{array}{l}\text { Statistic/ } \\
\text { index }\end{array}$ & $\begin{array}{l}\text { Narragansett } \\
\text { Bay }\end{array}$ & $\begin{array}{c}\text { Delaware } \\
\text { Bay }\end{array}$ & $\begin{array}{c}\text { Chesapeake } \\
\text { Bay }\end{array}$ \\
\hline $\mathrm{GPP}\left(\mathrm{mg} \mathrm{C} \mathrm{m} \mathrm{m}^{-2} \mathrm{yr}^{-1}\right)$ & 689616 & 654050 & 600453 \\
\hline $\begin{array}{l}\text { NetPP (pelagic and benthic) } \\
\text { (mg C m } \mathrm{m}^{-2} \mathrm{yr}^{-1} \text { ) }\end{array}$ & 403064 & 380592 & 333065 \\
\hline Sum of consumption (mg $\mathrm{C} \mathrm{m}^{-2} \mathrm{yr}^{-1}$ ) & 1790041 & 1383769 & 1493678 \\
\hline Sum of exports (mg C $\mathrm{m}^{-2} \mathrm{yr}^{-1}$ ) & 378017 & 411535 & 263696 \\
\hline Sum of respiration ( $\mathrm{mg} \mathrm{C} \mathrm{m} \mathrm{C}^{-2} \mathrm{yr}^{-1}$ ) & 31.6051 & 302848 & 625100 \\
\hline Flow to detritus (mg C m $\mathrm{m}^{-2} \mathrm{yr}^{-1}$ ) & 1687553 & 1275913 & 1231202 \\
\hline Sum of production (mg C m $\mathrm{m}^{-2} \mathrm{yr}^{-1}$ ) & 1273525 & 936008 & 907811 \\
\hline $\begin{array}{l}\text { Production/respiration ratio, } \\
\text { NetPP/R }\end{array}$ & 1.3 & 1.3 & 0.5 \\
\hline GPP/total respiration ratio & 2.2 & 2.2 & 1.0 \\
\hline $\begin{array}{l}\text { Net system production } \\
\left(\mathrm{mg} \mathrm{C} \mathrm{m}^{-2} \mathrm{yr}^{-1}\right)\end{array}$ & 87013 & 77744 & -292035 \\
\hline Biomass/production ratio & 24.2 & 28.2 & 30.3 \\
\hline $\begin{array}{l}\text { Production/biomass ratio } \\
\text { (NetPP/biomass) }\end{array}$ & 0.041 & 0.035 & 0.033 \\
\hline Biomass/throughput $\left(\mathrm{yr}^{-1}\right)$ & 0.004 & 0.004 & 0.003 \\
\hline $\begin{array}{l}\text { Total biomass (no detritus) } \\
\left.\text { (mg C m} \mathrm{m}^{-2} \mathrm{yr}^{-1}\right)\end{array}$ & 16636 & 13484 & 10992 \\
\hline Fishery mean trophic level & 4.43 & 4.51 & 4.25 \\
\hline Total catches ( $\mathrm{mg} \mathrm{C} \mathrm{m} \mathrm{m}^{-2} \mathrm{yr}^{-1}$ ) & 467 & 235 & 649 \\
\hline Fishery catch/NetPP ratio & 0.0012 & 0.0006 & 0.0020 \\
\hline $\begin{array}{l}\text { NetPP Eff\% (NetPP/total PP } \\
\text { consumption) }(\%)\end{array}$ & 40 & 67 & 42 \\
\hline NetPP/Total system consumption $(\%)$ & 22.5 & 27.5 & 22.3 \\
\hline Detritivory/herbivory ratio & 8.1 & 3.4 & 6.9 \\
\hline Overall connectance (no units) & 2.6 & 2.6 & 2.5 \\
\hline Internal connectance (no units) & 2.3 & 2.4 & 2.4 \\
\hline Food web connectance (no units) & 2.4 & 2.5 & 1.6 \\
\hline Omnivory index (no units) & 0.3 & 0.3 & 0.2 \\
\hline
\end{tabular}

\section{Biomass and throughput}

The lower standing biomass level in Chesapeake Bay can be partially attributed to the relatively low biomass of mesozooplankton and carnivorous fish in the Chesapeake estuary, as compared to Delaware and Narragansett Bays (Table 1, Fig. 4). Also, the Eastern oyster Crassostrea virginica is no longer prevalent in Chesapeake Bay for a number of reasons, including disease, predation, and overharvest (Stagg 1986, Newell 1988). Therefore, the contribution that oysters make to suspension feeding has been greatly reduced.

The differences in system activity are gauged by the values of the total system throughput (T) (Table 2). In descending order, system throughput ranked as Narragansett, Chesapeake and Delaware Bays (Table 2). The high throughput in Narragansett Bay was due in part to higher gross primary productivity, longer food chains. and greater cycling of carbon (Tables 1 \& 3). Although Chesapeake Bay had the lowest primary production, it ranked second in total system throughput. This was partially due to its greater physical size, which accommodates many habitats, and to its large import of detritus. Both of these factors can abet the throughput value by providing a larger number of compartments for carbon to flow through (Monaco et al. 1992). 
Table 2. Network analysis ecosystem indices for estuaries

\begin{tabular}{|lccc|}
\hline Index & $\begin{array}{c}\text { Narragansett } \\
\text { Bay }\end{array}$ & $\begin{array}{c}\text { Delaware } \\
\text { Bay }\end{array}$ & $\begin{array}{c}\text { Chesapeake } \\
\text { Bay }\end{array}$ \\
\hline Total system throughput & 5147600 & 4301600 & 4541500 \\
(mg $\mathrm{m}^{-2} \mathrm{y}^{-1}$ ) & & & \\
Development capacity & 21986000 & 18599000 & 19900000 \\
(mg C $\mathrm{m}^{-2} \mathrm{yr}^{-1}$; bits) & & & \\
Relative ascendency, A/Cd (\%) & 33.5 & 33.4 & 31.3 \\
Overhead on imports (\%) & 9.6 & 10.7 & 10.9 \\
Overhead on exports (\%) & 3.9 & 3.8 & 4.7 \\
Dissipative overhead (\%) & 11.5 & 12.8 & 17.0 \\
Redundancy (\%) & 41.5 & 39.3 & 36.1 \\
Internal capacity, Ci & 13351000 & 10617000 & 10223000 \\
(mg C m ${ }^{-2} \mathrm{yr}^{-1}$; bits) & & & \\
Internal ascendency, Ai & 4222300 & 3313200 & 3039800 \\
(mg C $\mathrm{m}^{-2} \mathrm{yr}^{-1}$; bits) & & & \\
Internal relative ascendency, Ai/Ci & 31.6 & 31.2 & 29.7 \\
Internal redundancy (\%) & 68.4 & 68.8 & 70.3 \\
Information content (bits) & 1.2 & 1.3 & 1.3 \\
Flow diversity (bits) & 4.3 & 4.3 & 4.4 \\
& & & \\
\hline
\end{tabular}

rous and planktivorous fish in these 2 estuaries were less than that of Narragansett Bay. Furthermore, the total system throughput of these larger estuaries was less than that of the much smaller Narragansett Bay. The total system throughput is a better indicator of estuary 'activity' than is system geometry (Baird et al. 1991). A major contributor to Narragansett Bay's system throughput is the relatively large total biomass of carnivorous fish $\left(1066 \mathrm{mg} \mathrm{C} \mathrm{m} \mathrm{m}^{-2}\right.$ ). The adult (greater biomass) life stages of predominantly marine species (e.g. bluefish Pomatomus saltatrix, tautog Tautoga onitis) contribute significantly to this biomass (Stone et al, 1994).

Trophic flows

Each of the estuaries possesses low system OI values, which ranged from

A small number of fish species (e.g. 13 in Delaware Bay) account for most of the fish biomass in midAtlantic estuaries (Smith 1982). Despite the fact that over 200 fish species have been recorded in Chesapeake Bay (Bulger et al. 1993) and over 100 species in Delaware Bay (Daiber 1988), the biomasses of carnivo-
0.17 to 0.29 . Thus, U.S. mid-Atlantic estuary food webs appear relatively linear in topology. Delaware Bay appeared to have the most web-like trophic structure based on the average of individual species and/or guild diets. Chesapeake Bay had the most specialized whole-system food web based on the OI (Table 1).

Table 3. Number and magnitude of carbon cycles over various path lengths in estuaries

\begin{tabular}{|c|c|c|c|c|c|}
\hline \multicolumn{6}{|c|}{ Distribution $(\%)$ of cycles per nexus } \\
\hline $\begin{array}{c}\text { No. of cycles } \\
\text { per nexus }\end{array}$ & $\begin{array}{c}\text { Narragansett } \\
\text { Bay }(\%)\end{array}$ & $\begin{array}{c}\text { No. of cycles } \\
\text { per nexus }\end{array}$ & $\begin{array}{c}\text { Delaware } \\
\text { Bay }(\%)\end{array}$ & $\begin{array}{l}\text { No. of cycles } \\
\text { per nexus }\end{array}$ & $\begin{array}{c}\text { Chesapeake } \\
\text { Bay }(\%)\end{array}$ \\
\hline 1 & 4.8 & 1 & 6.7 & 1 & 26.8 \\
\hline 2 & 0.9 & 2 & 6.7 & 2 & 21.4 \\
\hline 3 & 6.6 & 3 & 13.4 & 4 & 28.6 \\
\hline 4 & 7.0 & 4 & 4.5 & 5 & 8.9 \\
\hline 6 & 2.6 & 6 & 6.7 & 8 & 14.3 \\
\hline 8 & 3.5 & 8 & 4.5 & & \\
\hline 10 & 17.6 & 9 & 10.1 & & \\
\hline 12 & 5.3 & 14 & 15.6 & & \\
\hline 14 & 6.2 & 24 & 13.4 & & \\
\hline 15 & 6.6 & 33 & 18.4 & & \\
\hline 20 & 8.8 & & & & \\
\hline 32 & 14.1 & & & & \\
\hline 36 & 15.9 & & & & \\
\hline \multicolumn{6}{|c|}{ Percent of cycled flow through loops of various path lengths } \\
\hline Path length & & & & & Percent \\
\hline 2 & \multicolumn{2}{|c|}{80.0} & \multicolumn{2}{|c|}{73.0} & 67.0 \\
\hline 3 & \multicolumn{2}{|c|}{15.0} & \multicolumn{2}{|c|}{19.0} & 28.0 \\
\hline 4 & \multicolumn{2}{|c|}{5.0} & \multicolumn{2}{|c|}{7.0} & 5.0 \\
\hline 5 & \multicolumn{2}{|c|}{$<0.2$} & \multicolumn{2}{|c|}{$<0.2$} & $<0.2$ \\
\hline
\end{tabular}


The average trophic level of each compartment is shown in Fig 5. In each of the bays, consumer guilds appeared mostly at the second or third trophic levels. The top carnivores in Chesapeake Bay fed at a higher mean trophic position than their counterparts in Narragansett and Delaware Bays. The relatively lower trophic position of carnivorous fish in Delaware Bay can be attributed to the large degree to which these fish depended (both directly and indirectly) on the highly abundant mysid shrimp (Pennock \& Herman 1988).

Feeding webs that are very different in complexity and connections can be mapped into a standard network topology (Ulanowicz 1995). The standard form allows one to compare corresponding trophic efficiencies between estuaries (Baird et al. 1991). The trophic efficiency between levels is defined as the quotient of the amount a given level passes on to the next one, divided by how much it received from the previous level (Ulanowicz \& Wulff 1991). The energy flow networks pertaining to each estuary were mapped into simplified canonical trophic aggregations (Ulanowicz \& Kemp 1979, Monaco 1995). Each estuary exhibited high transfer efficiencies at the first trophic level, ranging from 62 to $69 \%$ (Monaco 1995). Chesapeake Bay was the most effective in transferring material $(31 \%$ efficiency) at the second trophic level. Thus, it had the greatest potential for transferring resources to the higher trophic compartments. This potential was reflected by the greater total catch of fish and macroin-

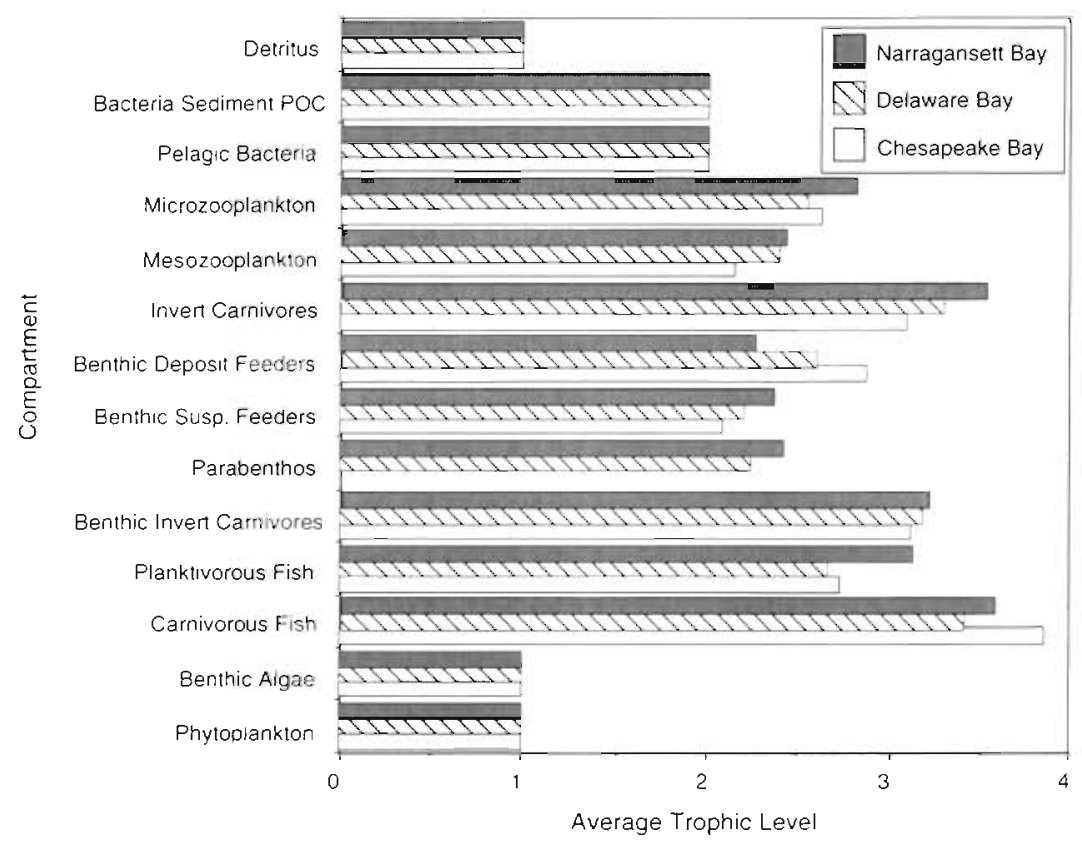

Fig. 5. Compartmental average trophic level in each estuary vertebrates in Chesapeake Bay, even though its total system biomass was much less than that of both Narragansett and Delaware Bays.

\section{Magnitude of cycling}

Important carbon recycling routes in Narragansett Bay are via pelagic and detrital pathways. Pelagic and benthic cycling pathways were proportioned similarly in the Delaware Bay network. The Chesapeake Bay ecosystem exhibited the least amount of cycling, and the benthic compartments (i.e. meiofauna and invertebrate carnivores) were the most important brokers in the bay's cycling network. Ulanowicz \& Wulff (1991) indicated that most of Chesapeake cycling occurred over 2 short benthic cycles: between the benthic deposit feeders and sediment $\mathrm{POC}$; and between benthic meiofaund and sediment POC

Both the once-through and cycled carbon in an ecosystem can be characterized by the average path length. The APL indicates the average number of trophic transfers a unit of medium (e.g. carbon) will experience between the time it enters and leaves the system (Baird et al. 1991). The APL for Narragansett Bay was 4.2 steps, followed by Chesapeake Bay with 3.3, and Delaware Bay at 2.8 transfers (Table 4). This means that a unit of carbon will be transferred about 1 more step in Narragansett Bay than in Chesapeake Bay, and about 1.5 more steps in Narragansett Bay than in Delaware Bay.

The Finn Cycling Index (FCI) reveals the proportion of total system throughput that is devoted to the recycling of carbon (Finn 1976). Thus, $\mathrm{FCl}=\mathrm{Tc} / \mathrm{T}$, where $\mathrm{Tc}$ is the amount of system activity involved in cycling and $T$ is total system throughput. Baird et al. (1991) demonstrated that the FCI was a better indicator of the physical retentiveness of material than it was a measure of stress. Odum (1971) indicated that mature systems would have a higher FCI value. The $\mathrm{FCl}$ percentage was greatest in Narragansett Bay (48\%), and decreased in Delaware (37\%) and Chesapeake (24\%) Bays. Finn's (1976) mean path length indicated that Narragansett Bay used longer pathways (6.01) as compared to the Delaware (4.97) and Chesapeake Bay (4.07) (Table 4). 
Table 4. FCl, retention, and cycling structure of estuaries. FCI: fraction of total system throughput devoted to recycling; APL: average number of compartments that an inflow/outflow passes through; FPL: average path length of recycled flow

\begin{tabular}{|c|c|c|c|c|c|}
\hline Estuary & $\begin{array}{l}\text { FCI } \\
(\%)\end{array}$ & $\begin{array}{c}\text { APL } \\
\text { (ratio) }\end{array}$ & $\begin{array}{c}\text { FPL } \\
\text { (ratio) }\end{array}$ & $\begin{array}{c}\text { Cycle } \\
\text { rate (no.) }\end{array}$ & $\begin{array}{l}\text { Flushing } \\
\text { rate (d) }\end{array}$ \\
\hline Narragansett Bay & 48.2 & 4.2 & 6.0 & 227 & 30 \\
\hline Delaware Bay & 37.3 & 2.8 & 5.0 & 179 & 100 \\
\hline Chesapeake Bay & 24.1 & 3.3 & 4.1 & 56 & 56 \\
\hline
\end{tabular}

\section{Cycling structure}

Important results from cycle analysis are the distribution of cycles into nexuses and the amounts of flow cycled over pathways of various lengths (Table 3). Narragansett Bay cycling occurred over a large number of nexuses with many cycles, and $95 \%$ of the cycled flow was via loops consisting of 2 or 3 transfers. Delaware Bay's cycled flow was distributed into fewer nexuses; however, approximately $60 \%$ of the cycles were grouped into many-cycled nexuses. As in Narragansett Bay, $92 \%$ of the cycled flow was over path lengths of 2 or 3 links. In contrast, Chesapeake Bay had a relatively low number of cycles and nexuses with a more even distribution of cycles per nexus. In Chesapeake Bay about $95 \%$ of cycled flow is via 2 or 3 transfers.

Narragansett Bay is a very active system as indicated by its high total system throughput. This throughput is maintained by the ecosystem recycling approximately $50 \%$ of its total flow over a multitude of cycles that contribute to a high system APL (Table 3). Even though the estuary flushes rapidly (Nixon 1983, NOAA 1990), a large proportion of carbon is recycled within the system, and even acyclic carbon is retained by sequential storage during the relatively long pathways through the food chain. Although the estuary is classified as a marine embayment (Monaco 1995), its cycling structure is fairly complex in light of its relatively high FCI and APL values, and its efficiency at retaining particulate matter.

All 3 estuaries are phytoplankton-dominated systems wherein large amounts of pelagic primary production are not being consumed and flow into the detritus compartment (Table 1). Monaco (1995) determined the proportion of total flow that was dependent upon outputs from the detritus compartment (Lindeman 1942, Ulanowicz \& Kemp 1979) by dividing the total flow originating from detritus by the total flow from both detritus and primary producers. Christensen \& Pauly (1992a) suggested that this ratio is an index of the importance of detritus in a system. It appears that the Chesapeake $(87 \%)$ and Narragansett (86\%) Bay ecosystems could rely more heavily on detritus than does the Delaware Bay ecosystem (79\%). Although a minimal amount of detritus is imported into Narragansett Bay, a large amount of carbon is recycled through the detritus, thereby inflating the ratio. The Chesapeake ecosystem exhibited a much lower $\mathrm{FCI}$, but it receives a large import of detritus (Table 1), which increases the detritus flow ratio. Although the detritus flow ratio was slightly lower in Delaware Bay, the reduced percentage was consistent with the bay's low $\mathrm{D} / \mathrm{H}$ ratio. Also, there is limited recycling through the detritus in the lower bay, because most of the primary production that occurs there is either exported or lost to the sediments (Pennock 1985). The amount of flow to detritus that ultimately was recycled back to the consumers differed in each system (Table 1). The ECOPATHil predatory cycling index excludes cycling through the detritus compartment. The fraction of flow recycled by consumers was $6.4 \%$ in Narragansett Bay, $8.6 \%$ in Delaware Bay, and $2.9 \%$ in Chesapeake Bay. Based on a rank order perspective, the combined set of indices indicates that the Delaware ecosystem relies more heavily on recycling of carbon via predator/prey interactions than via the uptake of detritus by microbiota.

The maturity and organization of ecosystems have been related to a greater degree of cycling (Odum 1969) and high relative ascendency (A/Cd) ratios (Baird et al. 1991). Ulanowicz \& Wulff (1991) concluded for the Baltic Sea ecosystem that a high FCI value and longer cycles provided a more developed apparatus for recycling. Thus, estuaries with both a relatively high FCI and many long cycles may not be as stressed as ecosystems that recycle carbon over short or fast trophic routes. Narragansett Bay had the largest FCI and the highest $\mathrm{A} / \mathrm{Cd}$ of all 3 estuaries.

\section{Food web interactions}

Network analysis at the whole-system level indicates that the trophic structure of Narragansett Bay is less impacted than that of Chesapeake and Delaware Bays. However, since it is often the responsibility of an estuarine resource administrator to manage a specific species, one would wish to know the effects that other compartments exert on particular species over all existing trophic pathways (i.e. direct and indirect consumption) (Ulanowicz \& Tuttle 1992). It is possible to address such questions using the power series of the diet matrix to estimate how much of various exogenous inputs eventually reach fishes and macroinvertebrates 
Table 5. Percentage of input (total contrbutions) from major sources that reach important compartments Carniv: carnuvorous; Planktiv.: planktivorous

\begin{tabular}{|llccc|}
\hline Source & Estuary & $\begin{array}{c}\text { Carniv. } \\
\text { fish }\end{array}$ & $\begin{array}{c}\text { Planktiv. } \\
\text { fish }\end{array}$ & $\begin{array}{c}\text { Benthic } \\
\text { suspension } \\
\text { feeders }\end{array}$ \\
\hline $\begin{array}{llccc}\text { Phytoplankton } \\
\text { production }\end{array}$ & $\begin{array}{l}\text { Narragansett Bay } \\
\text { Delaware Bay }\end{array}$ & 0.37 & 0.58 & 1.90 \\
Benthic & Chesapeake Bay & 0.05 & 0.35 & 0.72 \\
production & Narragansett Bay & 0.42 & 0.42 & 2.50 \\
Allochthonous & Delaware Bay & 0.29 & 0.60 & 1.60 \\
input & Chesapeake Bay & 0.12 & 0.09 & 0.46 \\
& Narragansett Bay & 0.41 & 0.36 & 0.46 \\
& Delaware Bay & 0.09 & 0.22 & 0.66 \\
& Chesapeake Bay & 0.10 & 0.19 & 1.00 \\
\hline
\end{tabular}

that have economic value (Table 5) (Szyrmer \& Ulanowicz 1987).

Because all of the estuaries were classified as phytoplankton-based ecosystems, the differences in the fractions of system inputs that reach the economically important guilds in each estuary should be greatest when phytoplankton production is used as the starting point (Table 5). For example, 1 unit of phytoplankton production in Narragansett Bay results in 4.6 times as much carnivorous fish produced there than occurs in Delaware Bay, and supports 7.4 times as much fish production as in Chesapeake Bay. In addition, phytoplankton in Narragansett Bay were about twice as efficient in producing planktivorous fish as was the case in Delaware and Chesapeake Bays. One unit of phytoplankton production in Chesapeake Bay resulted in 1.3 times as much benthic suspension feeder biomass than was produced in Narragansett Bay, and 3.5 times as much as in Delaware Bay.

Correlations between primary production and eventual fishery harvests or potential yields have been reviewed by Nixon (1983) and Polovina \& Marten (1982). A key measure for comparison is the fishery efficiency index (Christensen \& Pauly 1992a), which is calculated as the sum of all fisheries catch $\left(\mathrm{mg} \mathrm{C} \mathrm{m} \mathrm{m}^{-2}\right.$ $\mathrm{yr}^{-1}$ ) divided by the system's net primary production. This index varies widely among different aquatic ecosystems. Generally, the index attains high values in systems with fisheries that harvest low on the food chain (e.g. bait fisheries), and low values in systems with underexploited stocks or in those where fisheries concentrate on apex predators (Christensen \& Pauly 1992a). The index is dimensionless, because it is the ratio of 2 flows, and its numerical magnitude usually is much smaller than unity. For example, the weighted global average is approximately 0.0002 (Pauly \& Christensen 1995). Thus, the values for the estuaries, ranging as they do from 0.0006 to 0.0020 , is evidence for the high productivities of mid-Atlantic estuaries (Table 1). When compared to the other 2 estuaries, the Chesapeake Bay ecosystem was not as efficient in producing carnivorous finfish via phytoplankton production (Table 5). However, the overall catch to net primary production ratio, which indirectly receives subsidy from detrital inputs, was high, indicating that the fishery was very efficient in harvesting economically important living resources lower on the food chain (e.g blue crabs).

Chesapeake Bay supported the largest fishery (fish and invertebrates) harvest rate of $649 \mathrm{mg} \mathrm{C} \mathrm{m} \mathrm{m}^{-2} \mathrm{yr}^{-1}$, followed by Narragansett Bay at $467 \mathrm{mg} \mathrm{C} \mathrm{m}^{-2} \mathrm{yr}^{-1}$, and Delaware Bay at $235 \mathrm{mg} \mathrm{C} \mathrm{m} \mathrm{Cr}^{-1}$. The corresponding fishery efficiency indexes rank in the same order (Table 1). The mean trophic level at which fisheries were taking their harvests varied in each bay, Delaware Bay occurring highest on the trophic ladder and Chesapeake Bay the lowest (Table 1). Although Chesapeake Bay was more efficient in converting pelagic and benthic primary production into harvestable biomass, that fishery withdrew resources from lower in the food web than did the fisheries in Delaware and Narragansett Bays. The high index in Chesapeake is largely attributable to the great amount of commercial and recreational harvest of benthic macroinvertebrates (e.g. blue crab). Although Narragansett Bay is physically the smallest of the estuaries, it exhibited relatively high fishery exports (Lowery \& Monaco 1995). Furthermore, this harvest was dominated by marine finfish (e g. bluefish) and macroinvertebrates (e.g. American lobster Homarus americanus) species.

Table 6 shows the indirect diets of the major carnivorous and planktivorous fish found in each case study estuary. Pelagic primary producers appear more important to carnivorous fish in Narragansett $(53 \%)$ and Delaware Bays ( $41 \%)$ than they were to the same guild in Chesapeake Bay (29\%). In addition, the carnivorous fish in Narragansett and Delaware Bays depend heavily on parabenthic shrimp. Carnivorous fish in Chesapeake Bay depend very heavily on benthic deposit feeders $(81 \%)$, bacteria sediment POC $(78 \%)$, and detritus (87\%). Mesozooplankton were more important to the planktivorous (filter-feeding) fish in Narragansett Bay (53\%) and Chesapeake Bay $(64 \%)$ than the mere $31 \%$ of the filter fish diet that was brokered by the mesozooplankton of Delaware Bay.

In comparing the Chesapeake ecosystem with that of the Baltic Sea, Ulanowicz \& Wulff (1991) concluded 
Table 6. Indirect diets (in \% of total consumption) of carnivorous and planktivorous fishes in estuaries, i.e. fraction of total consumption by species $j$ which passed through species $i$ along its way to $j$. Percents add to greater than 100, because the same carbon visits several compartments along its way to the specific consumer. POC: particulate organic matter; na: not applicable

\begin{tabular}{|c|c|c|c|c|c|c|}
\hline \multirow[t]{2}{*}{ Compartment } & \multicolumn{3}{|c|}{ Carnivorous fish } & \multicolumn{3}{|c|}{ Planktivorous fish } \\
\hline & $\begin{array}{c}\text { Narragansett } \\
\text { Bay }\end{array}$ & $\begin{array}{c}\text { Delaware } \\
\text { Bay }\end{array}$ & $\begin{array}{c}\text { Chesapeake } \\
\text { Bay }\end{array}$ & $\begin{array}{c}\text { Narragansett } \\
\text { Bay }\end{array}$ & $\begin{array}{c}\text { Delaware } \\
\text { Bay }\end{array}$ & $\begin{array}{c}\text { Chesapeake } \\
\text { Bay }\end{array}$ \\
\hline Carnivorous fish & 8.10 & 4.50 & 5.80 & 0.08 & 0.03 & 0.01 \\
\hline Planktivorous fish & 23.50 & 22.00 & 13.50 & 0.01 & 0.07 & 0.04 \\
\hline Benthic invert. carnivores & 6.90 & 7.30 & 7.10 & 0.05 & 0.21 & 0.30 \\
\hline Benthic suspension feeders & 2.60 & 6.10 & 2.10 & 0.42 & 1.00 & 0.51 \\
\hline Parabenthos & 34.40 & 59.60 & na & 21.10 & 22.40 & na \\
\hline Benthic deposit feeders & 50.30 & 17.60 & 81.20 & 12.30 & 2.10 & 3.40 \\
\hline Invertebrate carnivores & 2.10 & 0.05 & 0.13 & 3.10 & 0.11 & 0.08 \\
\hline Mesozooplankton & 24.80 & 22.30 & 12.60 & 53.20 & 30.70 & 64.30 \\
\hline Microzooplankton & 15.10 & 6.60 & 8.90 & 13.30 & 8.00 & 10.10 \\
\hline Pelagic bacteria & 29.90 & 20.80 & 11.50 & 28.50 & 22.90 & 11.00 \\
\hline Bacteria sediment POC & 38.20 & 25.90 & 77.90 & 25.20 & 16.80 & 14.70 \\
\hline Benthic algae & 15.90 & 31.50 & 9.70 & 12.80 & 20.80 & 2.50 \\
\hline Phytoplankton & 52.50 & 41.30 & 29.00 & 65.30 & 56.80 & 59.00 \\
\hline Detritus & 64.50 & 49.80 & 87.40 & 44.70 & 40.90 & 55.00 \\
\hline
\end{tabular}

that the former relied more on its benthic processes than did the latter. In the current study, benthic deposit feeders, bacteria sediment POC, and detritus were major contributors to the indirect diets of carnivorous fish in Chesapeake Bay, and also figured prominently in the recycling of carbon in that bay. In addition, in Chesapeake Bay the carnivorous fish are less tightly coupled to primary production products, and rely indirectly more on detritus than do their counterparts in Narragansett and Delaware Bays. The Chesapeake Bay relies heavily on benthic processes, whereas Narragansett Bay, and to a lesser extent Delaware Bay, may be more indifferent to perturbations in benthic habitats, because they draw their primary sustenance from pelagic primary production.

Hartman (1993) used bioenergetics models to determine the relative roles that the top predators-weakfish Cynoscion regalis, bluefish, and striped bass Morone saxatilus-played in the Chesapeake Bay ecosystem. He also quantified the amount and trophic sources of the prey required to fuel piscivore production. Although it has long been known that these pelagic predators feed predominantly via pelagic pathways, interesting trends in resource use were apparent. For example, a distinct decline occurred during the summer months in the use of pelagic resources (and thus an increase in the consumption of benthic prey) by age 2 striped bass. The use of benthic resources by age 1 bluefish and weakfish was also highest during the summer. In corroboration with the behavior that network analysis revealed at the system level, it also appears that benthic processes in Chesapeake Bay are highly important to particular populations of juvenile and adult piscivores.

\section{Ecosystem structure}

Development capacity: This index is a surrogate for the complexity of the food web. It was greatest in Narragansett Bay and lowest in Delaware Bay (Table 2). This index did not vary dramatically among the ecosystems; however, due to its logarithmic nature, small differences in the index can represent appreciable disparities in ecosystem structure.

Ascendency: This is a key property of a network of flows that quantifies both the aggregate intensity of process activities and the level of definition or specificity with which these processes occur (Ulanowicz \& Wulff 1991). In decreasing order, the ascendency ranked Narragansett Bay, Delaware Bay, and Chesapeake Bay.

Redundancy: This is the degree to which pathways in a network are parallel, so that the connection between any 2 compartments cannot be severed by elimination of a single intervening link (Ulanowicz \& Wulff 1991). Chesapeake Bay had the highest internal redundancy, followed by Delaware and Narragansett Bays.

Relative ascendency $(\mathrm{A} / \mathrm{Cd})$ : This ratio is an indication of system organization and efficiency. A trade-off between efficiency of flow (narrow or articulated food web as defined by Ulanowicz 1986) and system redundancy (web-like structure) occurs in aquatic ecosystems. In the most organized or articulated (linear) systems, the effects of an event (e.g. pollution episode) at any one compartment are propagated to only a small subset of the other compartments over the most efficient pathways. The relative ascendency ranking in descending order was Narragansett Bay, Delaware 
Bay, and Chesapeake Bay (Table 2). Although differences in the $\mathrm{A} / \mathrm{Cd}$ values were small, they nonetheless reflect larger changes in system efficiency because of the attenuating effect that logarithms introduce to the calculation

Values of the relative internal ascendency $(\mathrm{Ai} / \mathrm{Ci})$ do not differ greatly from the $\mathrm{A} / \mathrm{Cd}$ ratios. Baird et al. (1991) suggested that a large decrease in the $\mathrm{Al} / \mathrm{Ci}$ ratio in relation to $\mathrm{A} / \mathrm{Cd}$ could indicate a strong dependency of such a system on a few dominant external connections. Baird et al. (1991) demonstrated how Chesapeake Bay was more influenced by externalities than are larger marine ecosystems. When compared with many other aquatic ecosystems (41 in Christensen 1992, 6 in Baird et al. 1991), none of this study's estuaries exhibited dramatic differences in $\mathrm{A} / \mathrm{Cd}$ versus $\mathrm{Ai} / \mathrm{Ci}$ ratios. The largest of these differences in ratios occurred in Narragansett Bay. It is likely that limited exogenous inputs may be sufficient to stimulate the northern marine estuaries of the U.S. Atlantic coast (Monaco 1995).

In summary, the combination of cycling structure (magnitude of flows, APL, cycle lengths, and nexus size), $\mathrm{Ai} / \mathrm{Cl}$ ratios, system $\mathrm{P} / \mathrm{B}$ ratios, and harvest rates all lend support to the supposition that the Delaware and Chesapeake Bay ecosystems are more stressed than that of Narragansett Bay. It is not quite as clear, however, whether the Delaware is more stressed than the Chesapeake Bay.

Although the Chesapeake Bay ecosystem showed a high diversity of flows (Table 2), the low value of the omnivore index indicated a more specialized food web (Table 1). This can partly be explained by the dominance of detritus in structuring the estuarine food web. The influence of detritus on the system was reflected in the relatively high $\mathrm{D} / \mathrm{H}$ ratio in the Chesapeake Bay, and also by the very high overhead generated by system respiration (Table 2).

Ulanowicz (1986) defined an articulated food web as one more like a linear chain of one prey for each predator. Relative ascendency characterizes the overall efficiency of flow between ecosystem components, but the trophic topology may be more linear or weblike at any particular node in the web, depending on the diet of that species. Important commercial fishes in Delaware Bay were linked in a more narrow fashion, because most of their food was mediated through the parabenthos (primarily shrimp found in/near bottom sediments). Thus, any modification of habitat that impacts the parabenthos may have significant repercussions on the top predators in Delaware Bay (Monaco 1995). For example, in Delaware Bay the mysid shrimp are a significant item of prey for the economically important weakfish (Pennock \& Herman 1988)
It is also important to remember that the balance between ascendency and redundancy is modulated by 2 factors: the total number of links in a food web and the relative magnitudes of the flows between links. Because a necessary trade-off exists between the efficiency of energy transfer and redundancy of flow in any system, it is expected that estuaries with a relatively high $\mathrm{Ai} / \mathrm{Ci}$ ratio may be more stable with respect to internal perturbations of the estuarine food webs (e.g. habitat modifications). In this study, the Narragansett Bay ecosystem simultaneously had the highest $\mathrm{FCI}$, highest $\mathrm{Ai} / \mathrm{Ci}$ ratio, and the largest system redundancy of all 3 estuaries (Tables $2 \& 4$ ). It appears that the trade-off between trophic efficiency and the redundancy of energy flow is fairly balanced in Narragansett Bay. Delaware Bay had values for system efficiency (ascendency), overhead, redundancy, and FCI similar to those for Narragansett Bay. The Chesapeake Bay ecosystem had the lowest ascendency and highest internal redundancy of all 3 estuaries. The magnitudes of flow diversity were nearly the same in each bay; however, other indicators of food web connectance (Table 1) pointed to Delaware Bay as having the most complex food chains, followed by Narragansett and then Chesapeake Bay. Hence, based on a combination of $\mathrm{Ai} / \mathrm{Ci}$ ratios, cycling structure, and food web connectance indices, it appears that Delaware Bay is currently less impacted and has potentially more ability to mitigate perturbations to its food web than does Chesapeake Bay. Factors behind this conclusion may incluce (but are not limited to) the recent dramatic loss from Chesapeake Bay of benthic suspension feeders due to the decline of the Eastern oyster and the relatively low biomass of carnivorous fish.

Caution should always be taken when characterizing systems as impacted or stressed. In this study, the effects of stress referred specifically to a reduction in the organization of energy flow and carbon recycling structure within a food web. The results indicate that quantifying networks of trophic flows in mid-Atlantic estuaries set the stage for a number of useful comparisons, such as between the relative trophic status of estuarine communities, their structure and magnitude of cycling, and their estuarine-ecosystem-wide statistics and characteristics. Subtle similarities and differences have emerged that might not have been otherwise easily discerned. For example, the retentive cycling structure of Narragansett Bay has come to light.

Network analysis has been recommended and applied to aid in the management of estuarine and lake ecosystems (Moreau et al. 1993, Vega-Cendejas et al. 1993). This work demonstrates by comparative analyses how network analysis can support ecosystem managers in determining the trophic status or degree of 
development of estuarine ecosystems. Additionally, network analysis serves as a tool to assess the health of estuarine ecosystems and allows the manager to evaluate the entire estuarine community, rather than merely addressing apex fisheries (Christensen 1991, Mageau et al. 1995). Toward this end, network indices and quantitative features of the structure of energy transfers in the ecosystem serve to characterize the efficiency with which energy is transferred through taxa, and to assess the strength of direct and indirect trophic interactions throughout an estuary's food web. In particular, the application of network analysis to the trophic structures of geographically proximate estuaries should be central to the evolving discipline of comparative estuarine analysis.

\section{LITERATURE CITED}

Baird D. Glade JM, Ulanowicz RE (1991) The comparative ecology of six marine ecosystems. Philos Trans R Soc Lond $333: 15-29$

Baird D. Ulanowicz RE (1989) The seasonal dynamics of the Chesapeake Bay ecosystem. Ecol Monogr 59(4):329-364

Baird D, Ulanowicz RE (1993) Comparative study on the trophic structure, cycling and ecosystem propertins of four tidal estuaries. Mar Ecol Prog Ser 99:221-237

Briggs JC (1974) Marine zoogeography. McGraw-Hill Book Company, New York

Bulger AJ, Hayden BP, Monaco ME, Nelson DM, McCormickRay MG (1993) Biologically-based estuarine salinity zones derived from a multivariate analysis. Estuaries 16(2): $311-322$

Christensen V (1991) On ECOPATH, fishbyte, and fisheries management. Fishbyte 9(2):52-66

Christensen V (1992) Network analysis of trophic interactions in aquatic ecosystems. PhD dissertation, Universitetsparken Copenhagen

Christensen V, Pauly D (1992a) A guide to the Ecopathii software system (version 2.1). International Center for Living Aquatic Resources Management (ICLARM), Manila

Christensen V, Pauly D (1992b) Flow characteristics of aquatic systems. In: Christensen V, Pauly D (eds) Network analysis of trophic interactions in aquatic systems. International Center for Living Aquatic Resources Management (ICLARM), Manila, p 1-30

Coffin RB, Sharp JH (1987) Microblal trophodynamics in the Delaware estuary. Mar Ecol Prog Ser 41:253-266

Daiber FC (1988) Finfısh resources of the Delaware River estuary. In: Majumdar SK, Miller EW, Sage LE (eds) Ecology and restoration of the Delaware River Basin. Pennsylvania Academy of Science, Philadelphia, p 168-185

Day JW Jr, Smith WG, Wagner PR, Stowe WC (1973) Community structure and carbon budget of a salt marsh and shallow bay estuarine system in Louisiana. Louisiana State University Center for Wetland Resources, Baton Rouge

Field JG, Wulff F, Mann KH (1989) The need to analyze ecological networks. [n: Wulff F, Field JG, Mann KH (eds) Network analysis in marine ecology: methods and applications. Coastal and estuarine studies 32 . Springer-Verlag, Heidelberg, p 3-12

Finn JT (1976) Measures of ecosystem structure and function derived from analysis of flows. J Theor Biol 56:363-380

Gaedke U (1995) A comparison of whole-community and ecosystem approaches (biomass size distributions, food web analysis, network analysis, simulation models) to study the structure, function and regulation of pelagic food webs. J Plankton Res 6:1273-1305

Goodrich DM (ed) (1986) Delaware Bay: Issues, resources, status and management. NOAA Estuarme Programs Office, Washington, DC

Hartman KJ (1993) Striped bass, bluefish, and weakfish in the Chesapeake Bay: energetics, trophic linkages, and bioenergetics model applications. PhD dissertation, The University of Maryland, College Park

Jorgensen SE (1979) Handbook of environmental data and ecological parameters. International Society for Ecological Modelling, Copenhagen

Kay JJ, (ircham LA, Ulanowicz RE (1989) A detailed guide to network analysis. In: Wulff F, Field JG, Mann KH (eds) Network analysis in marine ecology: methods and appljcations. Coastal and estuarine studies 32 . Springer-Verlag Heidelberg, p 15-61

Leontief WW (1951) The structure of the Amencan economy, 1919-1939, 2nd edn. Oxford University Press, New York

Levine S (1980) Several measures of trophic structure applicable to complex food webs. J Theor Biol 83:195-207

Levinton JS (1982) Marine ecology. Prentice-Hall, Englewood Cliffs

Lindeman RL (1942) The trophic-dynamic aspect of ecology. Ecology 23:399-418

Lowery TA, Monaco ME (1995) National Estuarine Inventory fishery harvest: assignment of NMFS 1980-1990 landings statistics to East Coast estuaries. NOAA, Silver Spring, $\mathrm{MD}$

Mageau MT, Costanza R, Ulanowicz RE (1995) The development and initial testing of a quantitative assessement of ecosystem health. Eco Health 4:201-213

Mann KH (1982) Ecology of coastal waters: a systems approach. University of California Press, Berkeley

Mann KH, Field JG, Wulff. $F$ (1989) Network analysis in marine ecology: an assessment. In: Wuiff $F$, Field JG, Mann KH (eds) Network analysis in marine ecology: methods and applications. Coastal and estuarine studies 32. Springer-Verlag, Heidelberg, p 259-282

McCoy SE (ed) (1988) Chesapeake Bay: issues, resources, status and management. NOAA Estuarine Programs Office, Washington, DC

Monaco ME (1995) Comparative analysis of estuarine biophysical characteristics and trophic structure: defining ecosystem function to fishes. PhD dissertation, The University of Maryland, College Park

Monaco ME, Lowery TA, Emmett RL (1992) Assemblages of U.S. West Coast estuaries based on the distribution of fishes. J Blogeogr 19:251-267

Moreau J, Lijtvoet W, Palomares MLD (1993) Trophic relationships in the fish community of Lake Victoria, Kenya, with emphasis on the impact of Nile perch (Lates niloticus). In: Christensen V. Pauly D (eds) Trophic models of aquatic ecosystems. ICLARM Conf Proc 26. International Center for Living Aquatic Resources Management (ICLARM), Manila, p 144-152

Newell RIE (1988) Ecological changes in Chesapeake Bay: are they the result of over-harvesting the American oyster, Crassostrea virginica? ln: Understanding the estuary: advances in Chesapeake Bay research. Coastal Research Center, Gloucester Point, VA, p 536-546

Nixon SW (1983) Estuarine ecology-a comparative and experimental analysis using 14 estuaries and the MLRL microcosms. US EPA Chesapeake Bay Program, Annapolis, MD 
NMFS (National Marine Fisheries Service) (1.093) Fisheries of the United States 1992. Current Fishery Statistics No. 9200, May 1993. NMFS, Silver Spring, 11D

NMIFS (1994) Fisheries of the United States 1993. Current Fishery Statistics No. 9300, May 1994. NVIFS, Silver Spring, MD

NOAA (National Oceanic and Atmospheric Administration) (1987) Narragansett Bay: issues, resources, status and management. NOAA Estuarine Programs Office, Washington, DC

NOAA (1990) Estuaries of the United States: vital statistics of a national resource base. NOAA, Silver Spring, MD

NOAA (1991) Marine recreational fishery statistics survey, Atlantic and Gulf coasts, 1987-1989. Current Fisheries Statistics No. 8904, May 1991 NOAA, Silver Spring, MD

NOAA (1992) Marine recreational fishery statistics survey, Atlantic and Gulf coasts, 1990-1991. Current Fisheries Statistics Number 920, September 1992. NOAA, Silver Spring, $M D$

Odum EP (1969) The strategy of ecosystem development. Science 104:262-270

Odum EP (1971) Fundamentals of ecology. WB Saunders Philadelphia

Pauly D, Christensen V (1995) Primary production required to sustain global fisheries. Nature 374:255-257

Pennock JR (1985) Chlorophyll distributions in the Delaware estuary: regulation by light-limitation. Estuar Coast Shelf Sci 21:711-725

Pennock JR, Herman SS (1988). Plankton. In: Bryant TL, Pennock JR (eds) The Delaware Estuary: rediscovering a forgotten resource. University of Delaware Sea Grant Program, Newark, p 55-70

Polovina JJ (1984) An overview of the ECOPATH model. Fishbyte $2(2): 5-7$

Polovina JJ, Marten GG (1982) A comparative study of fish yields from various tropical ecosystems. In: Pauly D, Murphy GI (eds) Theory and management of tropical fisheries. ICLARM Conf Proc 9. International Center for Living Aquatic Resources Management (ICLARM), Manila, p 255-286

Smith RW (1982) Survey of selected marine fish populations in Delaware Bay, 1981 Delaware Division of Fish and Wildlife, Dover

Stagg C (1986) An evaluation of the information available for

Editorial responsibulity: Otto kinne (Editor),

Oldendorf/Luhe, Germany managing Chesapeake Bay fisheries: preliminary stock assessment, Vols I and II. University of Maryland Chesapeake Biological Laboratory, Solomons

Stone SL, Lowery TA, Field JD, Williams CD, Nelson D. Jury $\mathrm{SH}$, Monaco ME, Andreasen L (1994) Distribution and abundance of fishes and invertebrates in mid-Atlantic estuaries. NOAA, Silver Spring, MD

Szymer J, Ulanowicz RE (1987) Total flows in ecosystems. Ecol Model 53:123-136

Ulanowicz RE (1986) Growth and development: ecosystems phenomenology. Springer-Verlag, New York

Ulanowicz RE (1987) NETWRK: a package of computer algorithms to analyze ecological flow networks. University of Maryland Chesapeake Biological Laboratory, Solomons

Ulanowicz RE (1995) Ecosystem trophic foundations: Lindeman exonerata. In: Patten BC, Jorgensen SE (eds) Complex ecology: the part-whole relation in ecosystems. Prentice Hall, Englewood Cliffs, p 549-560

Ulanowicz RE, Kay JJ (1991) A package for the analysis of ecosystem flow networks. Env Software 6(3):131-142

Ulanowicz RE, Kemp WM (1979) Toward canonical trophic aggregations. Am Nat 114:871-883

Ulanowicz RE, Mann KH (1981) Ecosyslems under stress. In: Platt T, Mann KH, Ulanowicz RE (eds) Mathematical models in biological oceanography. UNESCO Press, Paris, p 133-137

Ulanowicz RE, Norden JS (1990) Symmetrical overhead in flow networks. Int J Sys Sci 21:429-437

Ulanowicz RE, Platt T (eds) (1985) Ecosystem theory for biological oceanography. Can Bull Fish Aquat Sci 213:1-260

Ulanowicz RE, Tuttle JH (1992) The trophic consequences of oyster stock rehabilitation in Chesapeake Bay. Estuaries 15(3):298-306

Ulanowicz RE, Wulff F (1991) Comparing ecosystem structures: the Chesapeake Bay and the Baltic Sea. In: Cole J. Lovelt $\mathrm{G}$, Findlay $\mathrm{S}$ (eds) Comparative analyses of ecosystems, pattern, mechanism, and theories. Springer-Verlag, New York, p 140-166

Vega-Cendejas ME, Areguin-Sanchez $F_{1}$ Hernandez $M$ (1993) Trophic fluxes on the Campeche Bank, Mexico. In: Christensen V, Pauly D (eds) Trophic models of aquatic ecosystems. ICLARM Conf Proc 26. International Center for Living Aquatic Resources Management (ICLARM), Manila, p 206-213

Submitted: October 31, 1996; Accepted: October 28, 1997 Proofs received from author(s): December 24, 1997 